
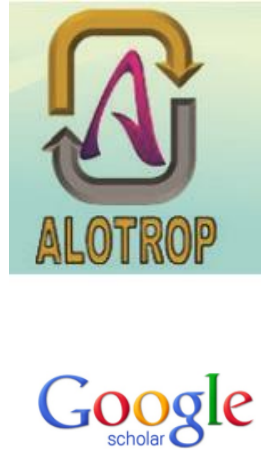

PROFIL FITOKIMIA DAN PENGARUH EKSTRAK TANGKAI DAUN

TALAS KEMUMU (Colocasia gigantea Hook.f) TERHADAP JUMLAH LEUKOSIT Mus musculus

Rofiqa Asri ${ }^{1}$,Dewi Handayani ${ }^{2}$,Agus Sundaryono ${ }^{*}$

1,2,3 Program Studi Pendidikan Kimia Jurusan PMIPA FKIP

Universitas Bengkulu

${ }^{3}$ E-mail : : sundaryono_2005@yahoo.fr

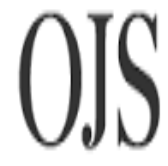

Open Journal Systems

\title{
$\underset{\text { MENDELEY }}{\text { Son }}$ Onesearch PKP|INDEX
}

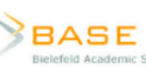

Academia.edu

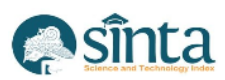

\begin{abstract}
This research aims to identify secondary metabolite compounds in Talas kemumu leaf stalk (Colocasia gigantea Hook.f) and to determine the effect of extract on the number of male Mus musculus leukocytes that have been induced aspirin. Aspirin is used to increase the number of M.musculus leucocytes. The method used in this research is the method of extraction by maceration to attract secondary metabolites of active compounds C.gigantea leaf stalk and the measurement of blood leukocyte counts are calculated using a hemocytometer (improved neubauer). Test of the effect of the leaf stalk of C.giganteaextract on the number leukocytes of M.musculus was performed by dividing into 5 groups with 5 replications according to the Federer formula, namely $\mathrm{K}(-)$ were given distilled water, $\mathrm{K}(+)$ were given aspirin, P1, P2 and P3 are each given a dose of extract of C.gigantea leaf stalk of $0,028 \mathrm{~g} / \mathrm{KgBB}, 0,056 \mathrm{~g} / \mathrm{KgBB}$ and $0,084 \mathrm{~g} / \mathrm{KgBB}$. The results showed that the identification of phytochemical profile in C.gigantea leaf stalk contains secondary metabolite compounds such as alkaloids, flavonoids, terpenoids, tannins and saponins. The results shows that giving of C.gigantea leaf stalk extract can reduce the number of leukocytes M.musculus which have induced aspirin. The giving of C.gigantea leaf stalk extract can decrease the number of aspirin-induced M.musculus leukocytes. This is evident from the results of One Way Anova analysis and the Smallest Real Difference Test (BNT) because in each treatment group has a significant influence. The effective dose that has the greatest activity in decreasing the number of M.musculus leukocytes found in the P1 treatment of $0,028 \mathrm{~g} / \mathrm{KgBB}$ can decrease the blood leukocyte count by $6,830 / \mathrm{mm}^{3}$.
\end{abstract}

Keywords: Colocasia gigantea Hook.f; Phytochemicals;Leukocytes; Mus musculus

\begin{abstract}
Abstrak
Penelitian ini bertujuan untuk mengidentifikasi senyawa metabolit sekunder dalam tangkai daun Talas kemumu (Colocasia gigantea Hook.f) dan mengetahui pengaruh pemberian ekstrak terhadap jumlah leukosit Mus musculusjantanyang telah diinduksi aspirin. Aspirin digunakan untuk meningkatkan jumlah leukosit M.musculus. Metode yang digunakan dalam penelitian ini adalah metode ekstraksi secara maserasi untuk menarik senyawa aktif metabolit sekunder tangkai daun C.gigantea dan pengukuran jumlah leukosit darah M.musculus dihitung menggunakan hemositometer (improved neubauer). Uji pengaruh ekstrak tangkai daun C.gigantea terhadap jumlah leukosit M.musculus dilakukan dengan membagi menjadi 5 kelompok perlakuan dengan 5 ulangan sesuai dengan rumus Federer yaitu $\mathrm{K}(-)$ yang diberi aquadest, $\mathrm{K}(+)$ diberi aspirin, P1, P2 dan P3 yang masing-masing diberi dosis efektif ekstrak tangkai daun C.gigantea sebesar $0,028 \mathrm{~g} / \mathrm{KgBB}, 0,056 \mathrm{~g} / \mathrm{KgBB}$ dan $0,084 \mathrm{~g} / \mathrm{KgBB}$. Hasil penelitian menunjukkan bahwa pada identifikasi profil fitokimia dalam tangkai daun C.giggantea mengandung senyawa metabolit sekunder antara lain alkaloid, flavonoid, terpenoid, tanin dan saponin. Pemberian ekstrak tangkai daun C.giganteadapat menurunkan jumlah leukosit M.musculus yang telah diinduksi aspirin. Hal ini terbukti dari hasil analisis One Way Anova dan Uji Beda Nyata Terkecil (BNT) karena pada setiap kelompok perlakuan memiliki pengaruh secara signifikan. Dosis efektif yang memiliki aktivitas paling besar dalam menurunkan jumlah leukosit M.musculus terdapat pada perlakuan P1 dosis $0,028 \mathrm{~g} / \mathrm{KgBB}$ dapat menurunkan jumlah leukosit darah sebesar $6.830 / \mathrm{mm}^{3}$.
\end{abstract}

Kata kunci: Colocasia gigantea Hook.f; Fitokimia; Leukosit; Mus musculus

\section{PENDAHULUAN}

Masyarakat Indonesia secara turun temurun telah lama mengenal dan menggunakan berbagai tanaman berkhasiat obat untuk menanggulangi masalah kesehatan [1]. Salah satu tanaman berkhasiat obat adalah Talas kemumu (Colocasia gigantea Hook.f).[2], yang digunakan umbinya untuk mengobati rasa kantuk, meredakan panas dalam, mengurangi masalah perut, menyembuhkan infeksi dan luka [3] serta sebagai obat menurunkan kadar gula darah [4]. Selain itu jus talas digunakan dalam pengobatan tuberkulosis, konstipasi, kanker darah dan menahan pendarahan arterial [5].

Hasil penelitian terdahulu membuktikan bahwa tangkai daun dari famili Colocasia memiliki kandungan berbagai senyawa metabolit sekunder seperti alkaloid, flavonoid, steroid, tanin dan saponin.[6].

Flavonoid merupakan senyawa metabolit sekunder yang mempunyai aktifitas beragam, 
diantaranya mempunyai efek sebagai antivirus, antikanker, antiinflamasi, antioksidan, antihepatoksik dan antidiabetes [7].

Darah sendiri terdiri atas dua bagian yaitu plasma darah dan sel darah [8]. Sel darah terdiri dari tiga jenis yaitu eritrosit, leukosit dan trombosit.[9] Leukosit bertanggung jawab terhadap sistem imun tubuh, untuk memusnahkan bendabenda yang dianggap asing dan berbahaya oleh tubuh, misal virus atau bakteri.[10]

Salah satu penyakit akibat kelebihan leukosit adalah Leukimia/kanker darah.[11], yang merupakan penyakit yang ditandai oleh proliferasi sel-sel darah putih, dengan manifestasi adanya selsel abnormal dalam darah tepi.[12]. Pada tahun 2006, leukemia berada pada urutan ke-5 dari keseluruhan kanker di Indonesia [12].

Untuk pengobatan penyakit kanker dapat dilakukan melalui cara kemoterapi, radioterapi dan pembedahan [13], namun hingga kini belum ditemukan obat yang dapat mengatasi penyakit kanker secara memuaskan karena memiliki kelemahan seperti harga obat mahal, rendahnya selektifitas obat-obatan, dan efek samping yang ditimbulkan [14].

Salah satu upaya alternatif pengobatan kanker darah adalah dengan upaya menemukan obat yang berpotensi menjadi antileukimia yang terkandung pada tanaman berkhasiat obat[15] seperti C.gigantea.

Berdasarkan uraian tersebut, peneliti tertarik untuk melakukan penelitian tentang profil fitokimia dan pengaruh ekstrak tangkai daun Talas kemumu (Colocasia gigantea Hook.f) terhadap jumlah leukosit pada Mus musculus.

\section{METODE PENELITIAN}

Sampel yang digunakan yaitu tangkai daun C.gigantea. Setelah tangkai daun dibersihkan dan dipotong kecil-kecil, kemudian dikeringkan dengan cara diangin-anginkan pada suhu kamar tanpa terkena sinar matahari langsung, dan selanjutnya sampel yang telah kering dihaluskan.

Identifikasi profil fitokimia dilakukan untuk mengetahui golongan senyawa yang terkandung di dalam tangkai daun C.gigantea. Identifikasi alkaloid dilakukan memasukkan 0,5 g sampel ke dalam tabung reaksi dan dilarutkan dengan $10 \mathrm{~mL}$ $\mathrm{HCl} 1 \mathrm{M}$ kemudian disaring. Filtrat dimasukkan ke dalam tabung reaksi dan ditetesi pereaksi Mayer's. Terbentuknya endapan putih atau krem mengindikasikan positif alkaloid [16].
Identiffikasi flavonoid dilakukan dengan melarutkan 0,5 g sampel tangkai daun C.gigantea kedalam $5 \mathrm{~mL}$ etanol dan dipanaskan selama lima menit di dalam tabung reaksi, dan selanjutnya ditambahkan beberapa tetes $\mathrm{HCl}$ pekat dan ditambahkan lagi dengan 0,2 g bubuk Mg. Hasil dinyatakan positif ditandai dengan timbulnya warna merah selama kurang lebih 3 menit [17]. Identifikasi terpenoid dan steroid menggunakan plat KLT dimana diaktivasi dengan pemanasan suhu $110^{\circ} \mathrm{C}$ dalam oven selama \pm 1 jam, setelah itu diberi tanda batas bawah $1 \mathrm{~cm}$ dan atas $1 \mathrm{~cm}$, lalu dilakukannya penotolan sampel ekstrak kental hasil rotary evaporator pada batas bawah plat KLT. Elusi yang digunakan adalah $n$-Heksan : etil asetat dengan perbandingan $6: 4$, plat KLT dimasukkan dalam chamber KLT yang ditutup.

Saat elusi yang sesuai telah mencapai tanda batas atas dan sudah diangin-anginkan, plat KLT diberi pelarut $\mathrm{H}_{2} \mathrm{SO}_{4}$ pekat menggunakan sprayer KLT dan dipanaskan kembali dengan suhu $50^{\circ} \mathrm{C}$ pada waktu 15 menit. Diamati plat KLT, jika terbentuknya warna ungu menunjukkan positif steroid dan terbentuknya warna merah kecoklatan atau merah keunguan menunjukkan positif terpenoid [18].

Untuk uji tanin, sebanyak $0,5 \mathrm{~g}$ sampel tangkai daun $C$.gigantea ditambahkan aquadest 10 $\mathrm{mL}$ lalu disaring, kemudian ditambahkan dengan 2-3 tetes larutan $\mathrm{FeCl}_{3} 1 \%$. Hasil positif mengandung senyawa tanin ditunjukkan dengan terbentuknya warna hitam kebiruan atau hijau [19]. Identifikasi saponin dilakukan dengan memasukan 0,5 g sampel tangkai daun C.gigantea ke dalam tabung reaksi dan ditambahkan dengan $10 \mathrm{~mL}$ aquadest hingga seluruh sampel terendam. Sampel tersebut dididihkan selama \pm 3 menit setelah itu sampel didinginkan dan selanjutnya disaring, kemudian filtrat dikocok selama \pm 15 menit. Hasil dinyatakan positif apabila ditandai dengan terbentuknya lapisan busa setinggi $2 \mathrm{~cm}$ [20].

Ekstraksi terhadap kandungan metabolit sekunder pada tangkai daun C.gigantea dilakukan secara maserasi dengan melakukan perendaman terhadap $1000 \mathrm{~g}$ serbuk tangkai daun kedalam pelarut etanol $96 \%$ didalam wadah kaca dan diletakkan pada tempat yang terlindungi dari sinar matahari selama 3x24 jam. Filtrat yang diperoleh disaring dan diuapkan dengan rotary evaporator hingga didapat ekstrak kental.

Mus musculus galur swiss webster yang digunakan adalah yang jantan telah dewasa dengan 
berat 20-40 g dan berumur 2-3 bulan. sebelum diberi perlakuan diadaptasikan terlebih dahulu selama 1 minggu. Kriteria inklusi $M$. musculus yang digunakan adalah yang berumur 2-3 bulan, berat sekitar 20-40 g, dan kriteria eksklusinya adalah tidak ada kelainan fisik.

Berdasarkan hasil dari rumus Federer yaitu (t-1) $(\mathrm{n}-1) \geq 15$, dengan $\mathrm{t}$ merupakan jumlah perlakuan dan $\mathrm{n}$ merupakan banyak pengulangan pada tiap perlakuan, sehingga didapatkan $n \geq 4,75$ dengan dropout $10 \%$ [21]. Penentuan subjek tiap kelompok dilakukan secara simple random sampling atau pemilihan acak sederhana [22].

Pengambilan dan pengamatan darah melalui ekor Mus musculus dilakukan untuk melihat pengaruh ekstrak tangkai daun $C$.gigantea terhadap jumlah leukositnya. Pada tahap awal M.musculus pada P0 (aspirin), P1, P2 dan P3 (sebagai perlakuan) diberi aspirin sesuai dengan dosis per oral . dengan menggunakan jarum gevage yang bertujuan untuk meningkatkan jumlah leukosit pada M.musculus.

Prinsip kerjanya adalah larutan yang dimasukkan ke dalam mulut M.musculus jantan secara perlahan-lahan kemudian diluncurkan melalui langit-langit kebelakang sampai esofagus sehingga larutan berakhir di lambung.

Pengambilan darah melalui ekor M.musculus dilakukan dengan dihisap menggunakan pipet leukosit sampai angka tepat 0.5 , kemudian ujung pipet dicelupkan ke dalam larutan Turk yang dihisap sampai angka 11, kedua ujung pipet ditutup dengan jari dan dibolak-balik dengan membentuk angka delapan selama kurang lebih tiga menit, dan selanjutnya diteteskan di atas kamar hitung, setelah ditutup dengan cover glass, preparat didiamkan selama satu menit untuk melisiskan leukosit.

Perhitungan jumlah leukosit dilakukan dengan menggunakan mikroskop dengan perbesaran $10 \mathrm{x}$ pada empat kotak besar kamar hitung dan jumlah leukosit yang ditemukan dikalikan dengan 50 yang merupakan jumlah leukosit permilimeter kubik $\left(\mathrm{mm}^{3}\right)$ darah [23].

Pembagian uji untuk masing masing perlakuan dapat dilihat pada Tabel 1 dan Tabel 2 .

Perhitungan jumlah leukosit dengan menggunakan rumus:

Jumlah Sel Darah Putih (SDP) $=$ Ne x 50

Dimana $\mathrm{Ne}=$ jumlah sel-sel darah putih dalam 4 kotak besar dipinggir.
Jumlah leukosit tiap milimeter kubik $\left(\mathrm{mm}^{3}\right)$ adalah jumlah sel terhitung dikalikan dengan 50 [24].

Tabel 1. Pengelompokan perlakuan pada Mus Musculus

\begin{tabular}{ccc}
\hline Perlakuan & $\begin{array}{c}\text { Dosis efektif } \\
\text { ekstrak tangkai } \\
\text { daun C.gigantea }\end{array}$ & $\begin{array}{c}\text { Jumlah Mus } \\
\text { musculus (ekor)/ } \\
\text { Ulangan }\end{array}$ \\
\hline $\begin{array}{c}\text { Kelompok 1 } \\
\text { (P0) }\end{array}$ & 0 & 5 \\
\hline $\begin{array}{c}\text { Kelompok 2 } \\
(\mathrm{P} 0)\end{array}$ & 0 & 5 \\
\hline $\begin{array}{c}\text { Kelompok } 3 \\
(\mathrm{P} 1)\end{array}$ & $0,028 \mathrm{~g} / \mathrm{Kgbb}$ & 5 \\
\hline $\begin{array}{c}\text { Kelompok } 4 \\
(\mathrm{P} 2)\end{array}$ & $0,056 \mathrm{~g} / \mathrm{Kgbb}$ & 5 \\
\hline $\begin{array}{c}\text { Kelompok } 5 \\
(\mathrm{P} 3)\end{array}$ & $0,084 \mathrm{~g} / \mathrm{Kgbb}$ & \\
\hline
\end{tabular}

Keterangan: Jarak waktu pengamatan darah 24 jam setelah diinduksi menggunakan jarum gevage.

Tabel 2. Pemberian perlakuan terhadap Mus musculus

\begin{tabular}{|c|c|c|c|c|}
\hline \multirow{2}{*}{$\begin{array}{l}\text { Kelompok } \\
\text { perlakuan }\end{array}$} & \multicolumn{4}{|c|}{ Perlakuan hari ke } \\
\hline & 1 & 2 & 3 & 4 \\
\hline $\begin{array}{c}\text { Kelompok } \\
1(\mathrm{P} 0)\end{array}$ & Aquadest & Aquadest & Aquadest & - \\
\hline $\begin{array}{c}\text { Kelompok } \\
2(\mathrm{P} 0)\end{array}$ & Aspirin & Aspirin & - & - \\
\hline $\begin{array}{c}\text { Kelompok } \\
3 \text { (P1) }\end{array}$ & Aspirin & Aspirin & $\begin{array}{l}\text { Ekstrak } \\
\text { tangkai daun } \\
\text { C.gigantea }\end{array}$ & - \\
\hline $\begin{array}{c}\text { Kelompok } \\
4 \text { (P2) }\end{array}$ & Aspirin & Aspirin & $\begin{array}{l}\text { Ekstrak } \\
\text { tangkai daun } \\
\text { C.gigantea }\end{array}$ & - \\
\hline $\begin{array}{c}\text { Kelompok } \\
5 \text { (P3) }\end{array}$ & Aspirin & Aspirin & $\begin{array}{l}\text { Ekstrak } \\
\text { tangkai daun } \\
\text { C.gigantea }\end{array}$ & - \\
\hline
\end{tabular}

Keterangan: pada hari ke 4 hanya dilakukan pengamatan darah tanpa diberikan perlakuan.

Data yang diperoleh dari hasil pengamatan dan perhitungan jumlah leukosit dalam darah M.musculus selanjutnya digunakan untuk penentuan jumlah dan rata-rata pada masingmasing perlakuan pada hari ke 1 sampai hari ke 4, Data yang diperoleh dianalisis dengan One Way Anova, dengan rumus:

JK Total

$$
=\sum X i^{2}-\frac{\left(\sum X i^{2}\right)}{N i}
$$

JK Perlakuan

$$
=\frac{\sum\left(X i^{2}\right)}{n}-\frac{\left(\sum X i^{2}\right)}{N i}
$$


JK Galat

$$
=\mathrm{JK} \text { Total }-\mathrm{JK} \text { Perlakuan }
$$

Jika F Hitung < F Tabel (Ho diterima dan Ha ditolak) maka menunjukkan hasil yang tidak signifikan dan apabila F Hitung > F Tabel maka akan dilanjutkan dengan Uji Beda Nyata Terkecil (BNT) dengan rumus

BNT 0.05 atau $0.01=(K-1)(N-K) \times \frac{\sqrt{K T G}}{r}$

\section{HASIL DAN PEMBAHASAN}

Pada penelitian ini sampel yang digunakan adalah tangkai daun Colocasia gigantea Hook. $\mathrm{f}$ yang diambil dari desa Rama Agung, Kecamatan Arga Makmur, Bengkulu Utara.

Sebanyak $35.000 \mathrm{~g}$ sampel basah dikeringkan selama 15 hari tanpa terkena sinar matahari langsung mengalami penyusutan atau perubahan berat sampel menjadi 4.659 g. Pada proses pengerinan sampel C.gigantea terjadi perubahan berat karena kadar air yang ada dalam tangkai daun C.gigantea telah hilang yaitu $86,7 \%$.

Identifikasi profil fitokimia adalah langkah awal yang penting dalam penelitian tentang tumbuhan obat untuk mengetahui senyawasenyawa aktif yang terkandung di dalam sampel yang digunakan. Senyawa yang diidentifikasi antara lain senyawa alkaloid, flavonoid, terpenoid, steroid, tanin dan saponin.

Data yang diperoleh terdapat pada Tabel 3.

Tabel 3. Hasil profil fitokimia serbuk tangkai daun C.gigantea

\begin{tabular}{|l|l|c|c|}
\hline \multicolumn{1}{|c|}{$\begin{array}{c}\text { Skrining } \\
\text { Fitokimia }\end{array}$} & \multicolumn{1}{|c|}{ Pereaksi } & Uji Positif & Hasil \\
\hline Alkaloid & Mayer's & $\begin{array}{c}\text { Endapan } \\
\text { putih }\end{array}$ & $\begin{array}{c}\text { Sangat } \\
\text { sedikit }\end{array}$ \\
\hline Flavonoid & $\begin{array}{l}\text { Etanol + } \mathrm{HCl}+ \\
\text { pita Mg }\end{array}$ & Merah & Sedikit \\
\hline Terpenoid & $\begin{array}{l}\text { Libermann- } \\
\text { Burchard }\end{array}$ & $\begin{array}{c}\text { Warna } \\
\text { merah } \\
\text { kecoklatan } \\
\text { Warna biru } \\
\text { sampai } \\
\text { kehijauan }\end{array}$ & Positif \\
\hline Steroid & $\begin{array}{l}\text { Libermann- } \\
\text { Burchard }\end{array}$ & $\begin{array}{c}\text { Hitam } \\
\text { kebiruan } \\
\text { / hijau }\end{array}$ & Sedikit \\
\hline Tanin & FeCl3 1\% & $\begin{array}{c}\text { Berbusa } \\
\text { Agak } \\
\text { Saponin }\end{array}$ & $\begin{array}{l}\text { Aquadest } \\
\text { mendidih }\end{array}$ \\
\hline
\end{tabular}

Pada uji alkaloid ini menggunakan pereaksi mayer's yang mengandung logam $\mathrm{Hg}$ dan KI yang akan membentuk kompleks endapan putih. Pada pengujian alkaloid dilakukan penambahan $\mathrm{HCl}$ sebelum ditambahkan pereaksi mayer's karena alkaloid bersifat basa sehingga direaksikan dengan pelarut yang mengandung asam dan jika senyawa alkaloid bereaksi dengan asam klorida akan membentuk garam yang mudah larut dalam air. Atom nitrogen pada alkaloid akan bereaksi dengan ion logam $\mathrm{K}^{+}$dari kalium tetraiodomerkurat(II) membentuk kompleks kalium-alkaloid yang mengendap [25].

Warna merah yang dihasilkan menandakan adanya flavonoid akibat dari reduksi oleh asam klorida pekat dan magnesium [26]. Identifikasi tanin dengan terbentuknya warna biru kehitaman atau hijau kehitaman setelah penambahan $\mathrm{FeCl}_{3}$ $1 \%$.

Tanin merupakan senyawa polar yang akan mudah larut dalam senyawa polar dan bersifat asam karena sifat mudah melepaskan gugus $\mathrm{H}^{+}[27]$. Terbentuknya warna hijau kehitaman atau biru pada sampel setelah ditambahkan dengan $\mathrm{FeCl}_{3}$ karena tanin akan membentuk senyawa kompleks dengan ion $\mathrm{Fe}^{3+}$ sebagai atom pusat dan tanin memiliki atom $\mathrm{O}$ yang mempunyai pasangan elektron bebas yang bisa mengkoordinasikan ke atom pusat sebagai ligannya.Identifikasi positif mengandung senyawa saponin terbukti dengan terbentuknya gelembung busa yang tetap selama 3 menit setinggi $\pm 2 \mathrm{~cm}$ setelah penambahan aquadest panas.

Senyawa saponin memiliki gugus polar dan nonpalar bersifat aktif pada permukaan sehingga saat dikocok dengan air saponin dapat membentuk misel. Pada struktur misel gugus polar menghadap ke luar sedangkan gugus nonpolarnya menghadap ke dalam. Keadaan inilah yang tampak seperti busa, karena itu dalam analisis ini dilihat kemampuan sampel dalam membentuk busa [28].

Ekstraksi yang digunakan pada langkah ini adalah ekstraksi dingin atau maserasi. Adapun prinsip dari proses ekstraksi adalah "like dissolve like" yang artinya senyawa polar akan larut dengan baik pada fase polar dan senyawa nonpolar akan larut dengan baik pada fase nonpolar.

Metode ini dilakukan dengan memasukkan serbuk tanaman yang dipilih yaitu tangkai daun C.giganteadan pelarut yang sesuai dalam wadah kaca yang tertutup rapat pada suhu kamar. 
Proses ini dihentikan ketika tercapai kesetimbangan antara konsentrasi senyawa dalam pelarut dengan konsentrasi dalam sel tanaman, dalam artian pada proses maserasi pelarut kembali bening pada saat pengumpulan ekstrak. Serbuk tangkai daun C.gigantea $1000 \mathrm{~g}$ diekstraksi dengan metode maserasi menggunakan pelarut etanol sebanyak 6 L. Hasil filtrat yang didapat diuapkan dengan rotary evaporator, sehingga didapatkan ekstrk kental sebanyak $100 \mathrm{~g}$ dengan rendemen sebesar $10 \%$.

Perlakuan P0 (aquadest) dilakukan untuk mengetahui jumlah sel leukosit dalam keadaan normal, P0 (aspirin) digunakan sebagai kontrol pengamatan bahwa jumlah leukosit berada di atas normal. Pada P1, P2 dan P3 juga diberikan aspirin untuk mengamati peningkatan jumlah leukosit yang kemudian akan diberikan ekstrak tangkai daun $C$.gigantea.

Pengamatan jumlah leukosit menggunakan mikroskop dimulai dari hari ke 2, dalam artian pada hari ke 1 telah diberikan aspirin sehingga jarak waktu antara pemberian aspirin dengan pengamatan dan perhitungan jumlah leukosit M.musculus adalah 24 jam. Pada hari ke 2 dilanjutkan dengan pemberian obat aspirin dan pada hari ke 3 diberikan ekstrak sebagai tahapan pemulihan pada jumlah leukosit M.musculus.

Perhitungan jumlah leukosit pada Mus musculus dilakukan menggunakan kamar hitung hemositometer (improved neubauer) yang amati pada mikroskop binokuler pada perbesaran $10 \mathrm{x}$ pada setiap empat bidang besar pinggir.

Pemberian obat aspirin secara oral akan masuk melalui mulut lalu obat akan menuju pada organ jaringan seperti hati yang kemudian dialirkan melalui darah keseluruh bagian tubuh M.musculus.

Aspirin dapat menyebabkan peradangan dan dapat menghambat produksi prostaglandin dengan menghambat enzim siklooksigenase (COX).

Terhambatnya prostaglandin akan menyebabkan terjadinya penyempitan pembuluh darah yang dapat menghambat aliran darah, sehingga leukosit yang berfungsi sebagai kekebalan tubuh akan keluar yang dapat menyebabkan pelebaran pembuluh darah.

Leukosit berpindah dan merangsang pemecahan neutrofil pada pembuluh darah secara terus-menerus sehingga menyebabkan terjadinya peningkatan netrofil (leukosit) yang terlekat pada dinding pembuluh darah secara cepat.
Berdasarkan hasil uji jumlah leukosit diperoleh hasil perhitungan pada Tabel 4 .

Tabel 4 Hasil perhitungan jumlah leukosit M.musculus

\begin{tabular}{|c|c|c|c|c|c|}
\hline \multirow[b]{2}{*}{$\begin{array}{l}\text { Perlaku } \\
\text { an }\end{array}$} & \multirow[b]{2}{*}{$\mathrm{N}$} & \multicolumn{4}{|c|}{$\bar{X} \pm \mathrm{SD}\left(10^{3} / \mathrm{mm}^{3}\right)$} \\
\hline & & $\begin{array}{l}\text { Hasil } \\
\text { pengamat } \\
\text { an Hari } \\
\text { ke } 1\end{array}$ & $\begin{array}{c}\text { Hasil } \\
\text { pengamatan } \\
\text { Hari ke } 2\end{array}$ & $\begin{array}{c}\text { Hasil } \\
\text { pengamatan } \\
\text { Hari ke } 3\end{array}$ & $\begin{array}{c}\text { Hasil } \\
\text { pengamat } \\
\text { an Hari } \\
\text { ke } 4\end{array}$ \\
\hline $\begin{array}{l}\text { P0 } \\
(\mathrm{Aq})\end{array}$ & 5 & $\begin{array}{l}6,3 \pm \\
0,610\end{array}$ & $\begin{array}{c}7,04 \pm \\
0,900\end{array}$ & $\begin{array}{c}6,25 \pm \\
0,655\end{array}$ & $\begin{array}{l}7,71 \pm \\
0,885\end{array}$ \\
\hline $\begin{array}{l}\text { P0 } \\
\text { (A) }\end{array}$ & 5 & $\begin{array}{c}14,7 \pm \\
3,547\end{array}$ & $\begin{array}{c}16,1 \pm \\
2,063\end{array}$ & $\begin{array}{c}14,77 \pm \\
2,010\end{array}$ & $\begin{array}{c}11,15 \pm \\
1,289\end{array}$ \\
\hline $\mathrm{P} 1$ & 5 & $\begin{array}{c}12,21 \pm \\
1,885\end{array}$ & $\begin{array}{c}13,34 \pm \\
1,441\end{array}$ & $\begin{array}{c}7,99 \pm \\
0,990\end{array}$ & $\begin{array}{c}6,83 \pm \\
0,517\end{array}$ \\
\hline $\mathrm{P} 2$ & 5 & $\begin{array}{c}11,66 \pm \\
2,270\end{array}$ & $\begin{array}{c}13,34 \pm \\
1,441\end{array}$ & $\begin{array}{c}10,23 \pm \\
0,404\end{array}$ & $\begin{array}{c}9,43 \pm \\
1,002\end{array}$ \\
\hline P3 & 5 & $\begin{array}{c}10,85 \pm \\
1,649\end{array}$ & $\begin{array}{c}14,99 \pm \\
1,980\end{array}$ & $\begin{array}{c}10,56 \pm \\
1,039\end{array}$ & $\begin{array}{c}10,22 \pm \\
0,955\end{array}$ \\
\hline
\end{tabular}

Hasil pada uji anova hari ke 1 menyatakan bahwa hasil berbeda nyata atau signifikan karena $F_{\text {hitung }}(9,636297)>F_{\text {tabel }}(2,87)$, sehingga $\mathrm{H} 0$ ditolak dan Ha diterima.

Pada pengamatan hari ke 2 diperoleh data bahwa telah terjadi peningkatan jumlah leukosit dalam keadaan tidak normal, yaitu $12.000 / \mathrm{mm}^{3} \mathrm{ke}$ atas, kecuali pada perlakuan kontrol aquadest atau P0(aquadest) yang tetap berada keadaan leukosit normal.

Terjadinya peningkatan jumlah leukosit pada P0 (A), P1, P2 dan P3 setelah diberikan aspirin menunjukkan adanya suatu proses infeksi dalam organ tubuh M.musculus.

Produksi jumlah leukosit dalam tubuh M.musculus memiliki kecepatan yang berbedabeda, hal ini bergantung pada daya pertahan tubuh pada masing-masing hewan uji.

Data pada hari ke 2 menyatakan bahwa hasil berbeda nyata atau signifikan dengan $F_{\text {hitung }}$ $(22,103553)>F_{\text {tabel }}(2,87)$, yang artinya pada hari kedua mampu menaikkan jumlah leukosit M.musculus jantan pada P0 (A). P1, P2 dan P3 setelah diberi aspirin.

Pada hari ke 3 perlakuan $\mathrm{P} 1, \mathrm{P} 2$ dan $\mathrm{P} 3$ telah diberikan ekstrak tangkai daun C.gigantea sebagai fungsi penurunan jumlah leukosit menandakan kembali normal. 
Hasil uji anova $F_{\text {hitung }}(38,48898)>F_{\text {tabel }}$ $(2,87)$ dengan $\alpha=0,05$, maka hasilnya berbeda nyata atau signifkan dalam mempengaruhi jumlah leukosit dengan menurunkan jumlah leukosit M.musculus jantan pada P1, P2 dan P3 setelah diberikan ekstrak pada masing-masing dosis perlakuan.

Data dilanjutkan pada uji BNT menunjukkan bahwa P1, P2 dan P3 yang telah diberi ekstrak tidak berbeda nyata dengan P0 (aquadest), tetapi sangat berbeda nyata dengan P0 (aspirin).

Berdasarkan uji anova dan BNT terlihat bahwa dosis yang paling efektif dalam menurunkan jumlah leukosit M.musculus jantan adalah pada dosis $0,028 \mathrm{~g} / \mathrm{KgBB}$ pada perlakuan $\mathrm{P} 1$, karena dilihat dari nilai selisih pada uji BNT dengan membandingkan antara P0 (A) dengan P1, P2 dan P3.

Pada dosis $0,028 \mathrm{~g} / \mathrm{KgBB}$ merupakan dosis yang paling efektif dalam menurunkan jumlah leukosit darah M.musculus jantan hal ini disebabkan pada konsentrasi rendah dari dosis pada P2 dan P3 ternyata sangat bermanfaat secara farmokologi, karena dengan dosis yang kecil maka efek yang diharapkan untuk menurunkan jumlah leukosit M.musculus tercapai.

Setiap senyawa yang memiliki aktivitas biologi yang tinggi pada umumnya juga memiliki toksisitas yang tinggi. Semakin kecil dosis yang digunakan untuk pengobatan maka semakin rendah pula jumlah senyawa toksik yang dimasukkan ke dalam tubuh [29].

Pada hari ke 4 hanya dilakukan pengamatan jumlah leukosit pada M.musculus dengan hasil uji anova $F_{\text {hitung }}(17,073990)>F_{\text {tabel }}(2,87)$ maka hasil berbeda nyata atau signifikan dalam mempengaruhi jumlah leukosit dengan menurunkan jumlah leukosit M.musculus pada P1, P2 dan P3 setelah diberi ekstrak C.gigantea.

Uji lanjutan BNT menyatakan dan menguatkan dari data hari ke 3 bahwa dosis yang paling efektif adalah pada P1 dengan dosis 0,028 $\mathrm{g} / \mathrm{KgBB}$ tidak berbeda nyata dengan perlakuan kontrol aquadest atau P0 (aquadest), tetapi sangat berbeda nyata dengan perlakuan kontrol aspirin atau P0 (aspirin), P2 dan P3.

Ekstrak tangkai daun C.gigantea memiliki kandungan senyawa metabolit sekunder seperti flavonoid yang berfungsi sebagai antikanker, dan juga senyawa metabolit sekunder lainnya seperti alkaloid, terpenoid, tanin dan saponin yang berkerja secara sinergis (saling menguatkan) antar sesama metabolit sekunder sebagai pencegahan penyakit [30].

Senyawa flavonoid memiliki kemampuan untuk menghentikan tahap awal reaksi, oleh karena itu flavonoid dapat menghambat peroksidasi lipid, menekan kerusakan jaringan oleh radikal bebas dan menghambat beberapa enzim [31], selain itu senyawa flavonoid mempunyai kemampuan untuk menghambat zat karsinogen atau zat penyebab kanker [32].

Mekanisme senyawa flavonoid sebagai antikanker ada beberapa teori yaitu pertama, flavonoid sebagai oksidan melalui mekanisme pengaktifan jalur apoptosis sel kanker [33].

Apoptosis adalah salah satu jenis kematian sel terprogram oleh organisme multisel untuk membuang sel yang sudah tidak diperlukan oleh tubuh.

Mekanisme apoptosis sel akibat fragmentasi DNA diawali dengan lepasnya rantai proksimal DNA oleh senyawa oksigen reaktif seperti radikal hidroksil [34].

Kedua, flavonoid sebagai penghambat proliferasi tumor/kanker dengan menghambat jalur tranduksi sinyal dari membran sel ke inti sel[35].

Ketiga, dengan menghambat aktivitas reseptor tirosin kinase yang meningkat berperan dalam pertumbuhan keganasan sel kanker [36].

Hasil penelitian menunjukkan bahwa tanin memiliki peranan biologis yang kompleks mulai dari pengendapan protein hingga pengkhelat logam serta berfungsi sebagai antioksidan biologis [37].

\section{SIMPULAN}

Hasil identifikasi profil fitokimia dalam tangkai daun Colocasia gigantea Hook.f (Talas Kemumu) terbukti mengandung senyawa metabolit sekunder berupa senyawa alkaloid, flavonoid, terpenoid, tanin dan saponin.

Pemberian ekstrak tangkai daun C.gigantea mampu menurunkan jumlah leukosit M.musculus jantan setelah diinduksi obat aspirin.

Ekstrak tangkai daun C.gigantea dengan dosis $0,028 \mathrm{~g} / \mathrm{KgBB}$ memiliki aktivitas yang besar dalam menurunkan jumlah leukosit dalam darah sebesar $6.830 / \mathrm{mm}^{3}$, sehingga berpotensi sebagai antileukimia.

Hal ini terbukti dari hasil uji hipotesis menggunakan One Way Anova bahwa setiap kelompok perlakuan berpengaruh signifikan. 


\section{SARAN}

Penelitian lanjutan dapat digunakan dosis efektif ekstrak dengan dosis lebih kecil dari 0,028 $\mathrm{g} / \mathrm{KgBB}$ agar dapat diamati pengaruh dosis terkecil dalam mempengaruhi penurunan jumlah leukosit Mus musculus.

Harapan dengan dosis yang lebih kecil telah mampu memberikan aktivitas yang besar dalam menurunkan jumlah leukosit Mus musculus dan disarankan dapat mengisolasi senyawa metabolit sekunder aktif untuk dapat digunakan sebagai bahan yang berpotensi sebagai obat antikanker 54eukemia.

\section{DAFTAR PUSTAKA}

[1] Amir, H , Bambang Gonggo Murcitro, AS Ahmad, Murni Nur Islamiah Kassim ,The Potential Use Of Phaleria macrocarpa Leaves Extract As An Alternative Drug For Breast Cancer Among Women Living In Poverty, Asian Journal For Poverty Studies (AJPS), 2017, 3(2): 138 - 145.

[2] Salim, M., Elida Mardiah, Febby Febrizal, Pengaruh Hidrolisis Enzimatis Terhadap Produksi Bioetanol Dari Umbi Talas (Colocasia gigantea Hook F), J. Ris. Kim, 2012: 5(2): 137-142.

[3] Ansori, M.R., Talas (Colocasia esculenta [L.] Schott) sebagai Obat Herbal untuk Mempercepat Penyembuhan Luka, J Agromed Unila, 2015: 2(2): 108-112.

[4] Sari, I.P., Endang Lukitaningsih, ,Rumiyati, Irfan Muris Setiawan., Indek Glikemik Uwi, Gadung Dan Talas Yang Diberikan Pada Tikus, Trad. Med. J., 2013: 18(3) : 127-131.

[5] Devi, Bonika N. and Ganesh C. Jagetia. Anticancer Activity of Colocasia gigantea (Blume) Hook. f. In Cultured Cell Lines. International Journal of Current Engineering and Scientific Research. 2017: 4 (9): 1-11

[6] Wijaya, B, A., Gayatri Citraningtyas, Frenly Wehantouw., Potensi Ekstrak Etanol Tangkai Daun Talas (Colocasia esculenta [L]) Sebagai Alternatif Obat Luka Pada Kulit Kelinci (Oryctolagus cuniculus), PHARMACON Jurnal Ilmiah Farmasi-UNSRAT,2014: 3(3):
211-219.

[7] Mohamad.H,Andriani.Y, Kamariah. B., Siang. C.C., Syamsumir, D.F., Alias, A., Radzi, S.A.M., Effect of drying method on anti-microbial, anti-oxidant activities and isolation of bioactive coumpounds from Peperomia pellucida (L) Hbk, Journal of Chemical and Pharmaceutical Research, 2015 : 7(9): 578-584.

[8] Fitryadi, K., Sutikno , Pengenalan Jenis Golongan Darah Menggunakan Jaringan Syaraf Tiruan Perceptron, Jurnal Masyarakat Informatika, 2017: 7 (1): 1-10.

[9] Kurniasih, Y., Reskiani Mulyani., Gambaran Eritrosit Pada Sdiaan Darah Tepi Pasien Malaria Di Puskesmas Sungai Pencur, Jurnal Endurance, 2018: 3(2): 226-231.

[10] Rafdinal, I., Amiruddin, , Nuzul Asmilia, Zuraidawati, , Arman Sayuti, Zuhrawati, Razali Daud, Perbedaan Jumlah Leukosit Setelah Transplantasi Kulit Secara Autograft Dan Isograft Pada Anjing Lokal (Canis lupus familiaris), Jurnal Medika Veterinaria , 2016: 10 (2): 144-146.

[11] Andriyanto, E., Pengenalan Penyakit Darah Pada Citra Darah Menggunakan Logika Fuzzy, Jurnal JITIKA, 2011: 5 (2) : 1-7

[12] Rendra, M., Rismawati Yaswir. Akmal M. Hanif. Gambaran Laboratorium Leukimia Kronik di Bagian Penyakit dalam RSUP Dr. Djamil Padang. Jurnal Kesehatan Andalas, 2013: 2 (3): 141145.

[13] Amir, H, Bambang Gonggo Murrcitro, , Uji Microtetrazolium (MTT) Ekstrak Metanol Daun Phaleriamacrocarpa (Scheff.) Boerl Terhadap Sel Kanker Payudara MCF7, Alotrop, 2017: 1 (1) : 27-32.

[14] Shinta R.,N., Bakti Surarso, Terapi Mual Muntah Pasca Kemoterapi, Jurnal THT - KL, 2016: 9(2): $74-83$.

[15] Hasanah, S.N., Lucie Widowati., Jamu Pada Pasien Tumor/ Kanker sebagai Terapi Komplementer, Jurnal Kefarmasian Indonesia, 2016: 6 (1): 49-59 
[16] Agustina, W., Nurhamidah, Dewi Handayani , Skrining Fitokimia Dan Aktivitas Antioksidan Beberapa Fraksi Kulit Batang Jarak (Ricinus communis L.), Alotrop , 2017: 1(2):117-122 .

[17] Rahayu ,S., Nunung Kurniasih, Vina Amalia., Ekstraksi Dan Indentifikasi Senyawa Flavonoid Dari Limbah Kulit Bawang Merah Sebagai Anti Oksidan Alami, al Kimiya, 2015: 2 (1): 1-8.

[18] Dwisari, F., Harlia, Andi Hairil Alimuddin, Isolasi Dan Karakterisasi Senyawa Terpenoid Ekstrak Metanol Akar Pohon Kayu Buta-buta (Excoecaria agallocha L.), JKK, 2016 : 5(3): 25-30.

[19] Ergina, Siti Nuryanti dan Indarini Dwi Pursitasari, Uji Kualitatif Senyawa Metabolit Sekunder Pada Daun Palado (Agave angustifolia) Yang Diekstraksi Dengan Pelarut Air Dan Etanol, $J$. Akad. Kim, 2014: 3(3): 165-172.

[20] Liem, A.F., Elizabeth Holle. Ivone Y Gemnafle , Sarah Wakum , Isolasi Senyawa Saponin dari Mangrove Tanjang (Bruguiera gymnorrhiza) dan Pemanfaatannya sebagai Pestisida Nabati pada Larva Nyamuk, Jurnal Biologi Papua, 2013: 5(1): 27-34.

[21] Saridewi, M.N., Meiskha Bahar, Anisah., Uji Efektivitas Antibakteri Perasan Jus Buah Nanas (Ananas comosus) Terhadap Pertumbuhan Isolat Bakteri Plak Gigi di Puskesmas Kecamatan Tanah Abang Periode April 2017, Biogenesis, 2017: 5 (2): 104-110.

[22] Raupong, M. Saleh AF, Hasruni Satya Taruma, Penaksiran Rataan Dan Varians Populasi Pada Sampel Acak Terstratifika Dengan Auxiliary Variable , JMSK, 2015: 12 (1): 9-18.

[23] April. H. Wardhana, E. Kencanawati, Nurmawati , Rahmaweni, C.B. Jatmiko , Pengaruh Pemberian Sediaan Patikan Kebo (Euphorbia Hirta L) Terhadap Jumlah Eritrosit, Kadar Hemoglobin , Dan Nilai Hematokrit Pada Ayam Yang Diinfeksi Dengan Eimeria Tenella, Jurnal Ilmu Ternak dan Veteriner, 2001: 6 (2): 126-133.

[24] Hervidea, R., Endang Linirin Widiastuti, Endang Nurcahyani,
Sutyarso , G.Nurgoho Susanto, Efek Ekstrak Metanol Makroalga Cokelat (Sargassum sp.), Merah (Gracillaria sp.) dan Taurin Terhadap Gambaran Histopatologi Hepar Mencit Jantan (Mus musculus) yang Diinduksi Benzo( $\alpha)$ Piren, Jurnal Biologi Indonesia , 2018: 14(1): 123-131.

[25] Risky, T.A., Suyatno, Aktivitas Antioksidan Dan Anti Kanker Ekstrak Metanol Tumbuhan Paku, Adiantum philippensis L, UNESA Journal of Chemistry, 2014: 3 (1): 89-95.

[26] Rumagit, H.M., Max R.J. Runtuwene, Sri Sudewi, Uji Fitokimia Dan Uji Aktivitas Anti Oksidan Dari Ekstrak Etanol Spons Lamellodysidea herbacea, PHARMACON Jurnal Ilmiah Farmasi UNSRAT, 2015: 4 (3): 183-192.

[27] Romadanu, Siti Hanggita Rachmawati, Shanti Dwita Lestari, Pengujian Aktivitas Antioksidan Ekstrak Bunga Lotus (Nelumbo nucifera) , FishtecH, 2014:3(1): 1-7.

[28] Agustina, S., Ruslan, Agrippina Wiraningtyas., Skrining Fitokimia Tanaman Obat Di Kabupaten Bima, Cakra Kimia (Indonesian E-Journal of Applied Chemistry) , 2016: 4 (1): 71-76.

[29] Andriani Y. Toksisitas Fraksi Aktif Steroid Ekstrak Daun Jati Belanda (Guazuma Ulmifolia Lamk.) Terhadap Aktivitas Serum Glutamat Oksalat Transaminase (SGOT) Dan Serum Glutamat Piruvat Transaminase (SGPT) Pada Tikus Putih, Jurnal Gradien, 2008 : 4 (2): 365-371.

[30] Ningsih,D.R., Zusfahair, Dwi Kartika., Identifikasi Senyawa Metabolit Sekunder Serta Uji Aktivitas Ekstrak Daun Sirsak Sebagai Anti Bakteri, Molekul, 2016: 11(1): 101 - 111

[31] Andriani, Y., Pengaruh ekstrak daun jati belanda (Guazuma ulmifolia Lamk.) terhadap bobot badan kelinci yang diberi pakan berlemak, Jurnal Gradien, 2005: 1(2): 74-76.

[32] Andriani, Y, Habsah Mohamad, M.N.I, Kassim., N.D. Rosnan., D.F. Syamsumir., J.Saidin., et al , Evaluation on Hydnophytum formicarum Tuber from Setiu Wetland (Malaysia) and 
Muara Rupit (Indonesia) for Anti bacterial and Antioxidant activities and anti-cancer Potency against MCF-7 and HeLa Cell. Journal of Applied Pharmaceutical Science, 2017: 7 (9) :30-37.

[33] Yosie Andriani, NHM Lazim, A Asari, F Mohamad, TST Muhammad, N Ismail, M Taib, H Amir, A Ahmad, Habsah Mohamad., Evaluation of selected echinoderms from peninsular Malaysia for cytotoxicity against HepG2 cells, antioxidant and antibacterial activities, and their metabolites profiling, Journal of Applied Pharmaceutical Science,2018: 8 (10): 32-38

[34] A.Mohamad,H., Rosmiati., Muhammad, T.S.T., Andriani,Y., Bakar, K., Ismail,N., Saidin,J., Latip, J., Musa, N., Perenrengi., Potential Secondary Metabolites from Marine Sponge Aaptos aaptos for Artherosclerosis and Vibriosis Treatments, NPC( Natural Product Communications), 2017 : 12 (8): 1227-1230.

[35] Andriani , Y, Leni Marlina , Habsah Mohamad, Hermansyah Amir, Siti Aisha M Radzi, Jasnizat Saidin, Anti -Inflammantory Activity Of Bacteria Associated With Marine Sponge (Haliclona Amboinensis) Via Reducting No Production And Inhibiting Cyclooxygenase 1-Cyclooxygenase-2, And Secretory Phospholipase A2 Activities , Asian J Pharm Clin Res, 2017: 10 (11): 95-100.

[36] Musa ,N. S, Nadia Madiha Ramli, Jaznizat Saidin,Yosie Andriani, Antioxidant And Cytotoxicity Propertise Of Ethyl Acetate Fractions Of Pandanus tectorius Fruit Against HELA Cell Line, Alotrop , 2017: 1(2): 106-112.

[37] Tonahi, J.M.M., Siti Nuryanti, Suherman, Antioksidan Dari Daun Sirih Merah (Piper crocatum), J. Akademika Kim, 2014: 3(3): 383-389.

Sitasi penulisan artikel ini adalah Rofiqa Asri1,Dewi Handayani,Agus Sundaryono., Profil Fitokimia Dan Pengaruh Ekstrak Tangkai
Daun Talas Kemumu (Colocasia gigantea Hook.f) Terhadap Jumlah Leukosit Mus musculus, Alotrop, 2019: 3(1): 48-56. 